\title{
Statistical Analysis of Crop Production Sustainability in India: A Micro Level Study
}

\author{
Varinderpal Kaur
}

\begin{abstract}
Punjab agriculture dominated by wheat-rice cropping cycle witnessed a quantum jump in agricultural production and productivity as the result of green revolution technology and contributed largely towards ensuring food security to India's growing population. But overtime, growth and production of crops in the state is on decline due to overexploitation of its natural resources. The state now faces the problem pertaining to sustainability of its agriculture. The present paper evaluates the extent of sustainability of crop production in Punjab. Sustainability has been measured using time trend analysis of Monteith (1990) and inferences of sustainability were drawn from contingency table. Further, geometric growth rates of total area and yields of all major crops were computed using methodology of Oyekale (2012). The results show that even though production of majority of the crops is sustainable but it will not be for very long. From 1966 to 2011, crops like Wheat $(0.6 \%)$, Cotton $(0.4 \%)$, Maize $(2.1 \%)$, Oilseeds (1.9\%), Pulses (3.6\%), Bajra (4.2\%), Barley (4\%), Sugarcane $(2.3 \%)$, Jowar $(4.6 \%)$ were sustainably cultivated while rice $(-1.4 \%)$ showed unsustainability. The findings suggest that for sustainability of crop production in Punjab, there is need for crop diversification and shift from input intensive agriculture to sustainable farming so as to conserve natural resources for future food security.
\end{abstract}

Index Terms-Sustainability, agriculture, sustainability index, crop production.

\section{INTRODUCTION}

Agriculture is main source of livelihood of the people around the world especially in the developing countries like India. Until about four decades ago, farmers practiced subsistence agriculture. Crop yields were depended on rainfall, internal resources and use of organic manures but yields were low. Farmers would grow more than one crop at a time in a field so as improve soil health. Farms were left fallow or legumes were rotated with crops so as to safeguard their production against weather variability and pest outbreaks. In these farming systems, the link between agriculture and environment was strong and signs of natural resource degradation were seldom evident [1].

The advent of Green Revolution in 1960s led to commercialization of Indian agriculture. High Yielding Variety seeds, irrigation, use of chemical fertilizers and pesticides form the core features of Green Revolution. Punjab state became pioneer in adoption of green revolution technology in India and made great strides in agriculture over time. The result was doubling and tripling of yields of wheat,

Manuscript received August 5, 2016; revised October 14, 2016.

Varinderpal Kaur is with the Department of Geography, Panjab University, Chandigarh, India (e-mail: varinderpalaulakh@gmail.com). rice and other crops and the state contributed largely towards ensuring food security to India's growing population. The state produces about $12 \%$ of the nation's food grains on only $1.4 \%$ of its area and is called 'breadbasket of the country'.

Punjab state is located in northwest of India with an area of 5.03 million hectares. It extends from $29.30^{\circ} \mathrm{N}$ to $32.32^{\circ} \mathrm{N}$ latitudes and from $73.55^{\circ} \mathrm{E}$ to $76.50^{\circ} \mathrm{E}$ longitudes. About $83 \%$ of its total geographical area is under agriculture with cropping intensity of about $188 \%$. About 70 percent of the population is engaged in agriculture and its allied activities. Due to increase in population, per capita availability of land and its productivity has declined. Average size of land holdings is just 3.77 hectares. In the last decade, food grain production in Punjab has increased by $2 \%$ only as against $8.6 \%$ growth in its population [2].

The state has fallen in the web of wheat and rice cropping cycle as a result of central and state policies like Minimum Support Price, effective procurement of these two crops, agricultural subsidies, free electricity and easy credit availability. Before green revolution, the state grew more than 250 varieties of different crops but now grows only two main crops- wheat and rice and one minor cash crop, cotton [3]. The consumption of chemical fertilizers and pesticides has also increased many folds and is highest in the country. The level of NPK ratio in Punjab state is 39:9:1 as against an ideal combination of 4:2:1 and national average of 7:3:1 [4].

The state has net irrigated area of 96 percent with cropping intensity of 190 percent. Of the total irrigated area of the state, only 26 percent is irrigated through canals while $73 \%$ of the area is irrigated through tubewells. As a result, the state has groundwater deficit of 9.7 MCM (million cubic meters) [5]. Out of total 20 districts in the state, only one fall under safe category and remaining fall under "Over-Exploited" category. As a result, the ground water is falling at an average rate of 55 $\mathrm{cm}$ in the state while in certain central parts by $75 \mathrm{~cm}$ [6].

Growth and production of crops in the state is on decline due to overexploitation of its natural resources. The natural resources like land, soil and water have been misused extensively by farmers without any consideration of sustaining them and now they are paying price for this misuse with diminishing returns from agriculture. The state now faces the problem pertaining to sustainability of its agriculture. So, the present paper partially evaluates sustainability of Punjab crop production using the trends of cultivated land (input) and yields (output) only as all other factors are taken to be constant.

\section{DATA SOURCE AND METHOD OF ANALYSIS}

\section{A. Data Sources and Period of Study}

The present study is based on secondary data. To obtain 
the mean differences of crops, area and yield indexes, state level statistics on area and yields of crops were compiled from Statistical Abstracts of Punjab for the period 1966 to 2011. The study period has been divided into two parts. First, the Green Revolution phase from (1966-1985) which recorded unprecedented development in agriculture and post green revolution phase (1986-2011) which witnessed adverse effects of this development on the natural resources.

\section{B. Estimation of Sustainability Index}

To assess sustainability of crop production, time trends analysis method by Monteith (1990) has been used. Mean differences of land area (output) and yields (input) of different crops were computed for two time periods. The t-test (test of statistical significance) was applied to compare means to find if a significant difference exists between them. Then, sustainability is determined from a contingency table of trends in inputs and outputs.

TABLE I: CONTINGENCY TABLE (MONTEITH, 1990)

\begin{tabular}{|c|c|c|c|}
\hline Outputs & \multicolumn{3}{|c|}{ Inputs } \\
\hline & Decreasing & Constant & Increasing \\
\hline Decreasing & Indeterminate & Unsustainable & Unsustainable \\
\hline Constant & Sustainable & Sustainable & Unsustainable \\
\hline Increasing & Sustainable & Sustainable & Indeterminate \\
\hline
\end{tabular}

But this method has a limitation that when both output and input values increase or decrease simultaneously, nature of sustainability is indeterminate. So, to overcome this limitation, geometric growth index method as used by Oyekale (2012) has been used to determine the sustainability index of crop production [7]. The cultivated land and yields have been calculated to determine the sustainability index. The assumption being that if the yield index is greater than land index, production is sustainable but if the yield index is lower than the latter, production is unsustainable.

The formula to calculate geometric growth index is given as:

$$
I_{t}=\sqrt[k]{\left(1+p_{1}\right)\left(1+p_{2}\right) \ldots .\left(1+p_{k}\right)} 1
$$

where, $I_{t}=$ Index of output and input used in period t, $p_{1}=$ Percentage growth rate between year $\mathrm{t}$ and $\mathrm{t}-1, \mathrm{k}=\mathrm{n}-1$ (where $\mathrm{n}$ is number of observations).

\section{FINDINGS OF ANALYSIS}

The mean differences of cultivated land area of the crops and their yields are computed for two time periods 1966-1985 and 1986-2011 respectively. Then t-test was applied to study the trend in the cultivated land and crop yields. Table II shows that the mean differences in land area cultivated and yield per hectare under major crops i.e. wheat and rice is statistically significant at 1 percent level which means the area and yields of both the crops has increased over time. The area of both these crops increased at the cost of all other crops because of easy procurement of these crops at minimum support price (MSP) by government. Also, to make India food secure nation, both central and state governments focused mainly on these two crops in the state. While the area under other crops has decreased as there is no assured price and procurement system. The crops worst hit after introduction of green revolution are Jowar and Bajra, as both their area and yields crops have declined. In case of barley, maize, pulses and oilseeds, the mean difference of their areas is negative while the yields are statistically significant at 1 percent. This implies that from 1966 to 2011, their area has reduced while yields have increased. As for cotton and sugarcane crops, area is not statistically significant at 5 percent but their yields are significant at 1 percent. So, it is inferred that increases in cotton and sugarcane production in this period is result of improvements in the yields and not from expansion in land. The increase in yields of crops in the state is due to assured irrigation, use of high yielding seeds and fertilizers.

When contingency table (Table I) is referred to determine sustainability of crops like wheat, rice, Jowar and bajra, the inference is indeterminate.

TABLE II: MEAN DIFFERENCE AND T-STATISTICS FOR LAND AREAS AND YIELDS OF CROPS DURING 1966-1985 AND 1986-2011

\begin{tabular}{|c|c|c|c|c|}
\hline \multicolumn{2}{|c|}{ YIELDS OF CROPS DURING 1966-1985 AND 1986-2011 } \\
\hline & $\begin{array}{c}\text { CULTIVATED AREA } \\
\text { Difference }\end{array}$ & T-statistics & $\begin{array}{c}\text { Mean } \\
\text { Difference }\end{array}$ & T-statistics \\
\hline Wheat & 828917.692 & $8.270^{*}$ & 1581.2577 & $11.712^{*}$ \\
\hline Rice & 1534465.385 & $12.158^{*}$ & 1131.4577 & $6.902^{*}$ \\
\hline Barley & -49245.000 & $-5.517^{*}$ & 1806.3846 & $14.825^{*}$ \\
\hline Jowar & -2480.000 & $-5.069^{*}$ & -20.0417 & -0.193 \\
\hline Bajra & -113787.692 & $-8.148^{*}$ & -19.0077 & -0.525 \\
\hline Maize & -277128.077 & $-11.190^{*}$ & 880.1038 & $6.007^{*}$ \\
\hline Pulses & -270131.538 & $-8.199^{*}$ & 93.0923 & $3.442^{*}$ \\
\hline Oilseeds & -142205.385 & $-7.129^{*}$ & 326.6154 & $9.511^{*}$ \\
\hline Cotton & 53327.308 & 1.840 & 186.7731 & $5.745^{*}$ \\
\hline Sugarcane & -5030.769 & -0.663 & 10739.6115 & $4.279^{*}$ \\
\hline \multicolumn{7}{|c|}{ Statistically significant at <0.01* and <0.05** level } \\
\hline
\end{tabular}

Source: Computed from Statistical Abstracts of Punjab

So, geometric growth index method has been used to measure sustainability of crop production due to this flaw in time trend analysis of Monteith. This method is based on the assumption that if yield index of a crop is greater than its proportionate land index, its production is sustainable. But if land index is greater than yield index, production of crop is unsustainable.

TABLE III: SUSTAINABILITY INDEX OF CROP PRODUCTION IN PUNJAB (1966

\begin{tabular}{|c|c|c|c|c|}
\hline Crops & $\begin{array}{c}\text { Yield } \\
\text { Index }\end{array}$ & $\begin{array}{c}\text { Land } \\
\text { Index }\end{array}$ & $\begin{array}{c}\text { Sustainability } \\
\text { Index }\end{array}$ & Inference \\
\hline Wheat & 1.022 & 1.0174 & 0.0046 & Sustainable \\
\hline Rice & 1.0263 & 1.0483 & -0.022 & Unsustainable \\
\hline Barley & 1.0254 & 0.9809 & 0.0445 & Sustainable \\
\hline Jowar & 1.0213 & 0.942 & 0.0793 & Sustainable \\
\hline Bajra & 1.0017 & 0.9542 & 0.0475 & Sustainable \\
\hline Maize & 1.0036 & 0.986 & 0.0176 & Sustainable \\
\hline Pulses & 1.01 & 0.9711 & 0.0389 & Sustainable \\
\hline Oilseeds & 1.0038 & 0.9887 & 0.0151 & Sustainable \\
\hline Cotton & 1.0091 & 1.0068 & 0.0023 & Sustainable \\
\hline Sugarcane & 1.0224 & 0.9819 & 0.0405 & Sustainable \\
\hline
\end{tabular}

Source: Computed from Statistical Abstracts of Punjab

Table III shows that production of all crops except that of rice is sustainable during the period 1966-1985. Sustainability index is highest that of jowar while lowest of cotton crop. The kharif season crops like jowar, bajra, maize, pulses, cotton and sugarcane are sustainable, but farmers 
prefer unsustainable rice crop because it is more lucrative compared to former.

The sustainable index of rice is -0.02 which implies that increase in rice production was result of expansion in its area as compared to yield. The areal expansion of rice crop from 5 percent in 1966 to 24 percent of gross cropped area by 1985 , come at the cost of other crops like jowar, bajra, maize, and oilseeds. While the growth rate of rice yields fell from about 4 percent in 1970 s to 1.3 percent during the 1980 s [8]. In case of wheat, the area was already 31 percent in 1966 which increased to 43 percent in 1985 . So, most of the production in wheat during this period was due to high yields.

TABLE IV: SUSTAINABILITY INDEX OF CROP PRODUCTION IN PUNJAB (1986

\begin{tabular}{|c|c|c|c|c|}
\hline Crops & $\begin{array}{c}\text { Yield } \\
\text { Index }\end{array}$ & $\begin{array}{c}\text { Land } \\
\text { Index }\end{array}$ & $\begin{array}{c}\text { Sustainability } \\
\text { index }\end{array}$ & Inference \\
\hline Wheat & 1.0092 & 1.0017 & 0.0075 & Sustainable \\
\hline Rice & 1.0023 & 1.0076 & -0.0053 & Unsustainable \\
\hline Barley & 1.013 & 0.9767 & 0.0363 & Sustainable \\
\hline Jowar & 1 & 0.9862 & 0.0138 & Sustainable \\
\hline Bajra & 0.9968 & 0.9601 & 0.0367 & Sustainable \\
\hline Maize & 1.0136 & 0.9888 & 0.0248 & Sustainable \\
\hline Pulses & 0.9996 & 0.9662 & 0.0334 & Sustainable \\
\hline Oilseeds & 1.0083 & 0.9838 & 0.0245 & Sustainable \\
\hline Cotton & 1.0064 & 0.9998 & 0.0066 & Sustainable \\
\hline Sugarcane & 1.0023 & 0.9959 & 0.0064 & Sustainable \\
\hline
\end{tabular}

Source: Computed from Statistical Abstracts of Punjab

Table IV shows that again the production of all major crops in the time period from 1985-2011 is sustainable except that of rice. The sustainable index of rice is -0.005 . This implies that in this period again the increase in rice production is the result of expansion. The area reached 36 percent of gross cropped area in 2011 (from 24 percent in 1985). The growth rate of rice yields dropped to mere 0.02 percent by 2000s [9]. The expansion in area came at the cost of other crops such as cotton whose cultivated area came down to almost half by 1991. The area of cotton crop declined due to stagnation in its production largely due to fall in profitability to farmers caused by insecticide resistant pests like American bollworm [10]. In case of wheat, the area under wheat increased by just 2 percent in this period which shows that its area has reached saturation. The increase of wheat production is result of yields but these too are diminishing. Average annual growth rate of wheat yields declined from 2 percent in 2000s and to less than one percent by 2011 [11]. The constraint imposed by declining water-table, pest and disease vulnerability are adversely affecting rice yield more significantly than wheat yields [12].

Sustainability index is highest that of barley while lowest of cotton and sugarcane crops. The sustainability index of all crops in post green revolution shows decline in their index values as compared to green revolution period. This shows that that the yields of all the crops are stagnating or declining over time especially rice and wheat indicating technology fatigue. So, the future growth in agriculture with the present crop patterns and technology is only possible through area expansion but this option is also limited due to already high levels of cropping intensity of 190 percent in the state [13].
TABLE V: SUSTAINABILITY OF CROP PRODUCTION IN PUNJAB (1966-

\begin{tabular}{|c|c|c|c|c|}
\hline Crops & $\begin{array}{c}\text { Yield } \\
\text { Index }\end{array}$ & $\begin{array}{c}\text { Land } \\
\text { Index }\end{array}$ & $\begin{array}{c}\text { Sustainability } \\
\text { index }\end{array}$ & Inference \\
\hline Wheat & 1.0156 & 1.00955 & 0.00605 & Sustainable \\
\hline Rice & 1.0143 & 1.02795 & -0.01365 & Unsustainable \\
\hline Barley & 1.0192 & 0.9788 & 0.0404 & Sustainable \\
\hline Jowar & 1.01065 & 0.9641 & 0.04655 & Sustainable \\
\hline Bajra & 0.99925 & 0.95715 & 0.0421 & Sustainable \\
\hline Maize & 1.0086 & 0.9874 & 0.0212 & Sustainable \\
\hline Pulses & 1.0048 & 0.96865 & 0.03615 & Sustainable \\
\hline Oilseeds & 1.00605 & 0.98625 & 0.0198 & Sustainable \\
\hline Cotton & 1.00775 & 1.0033 & 0.00445 & Sustainable \\
\hline Sugarcane & 1.01235 & 0.9889 & 0.02345 & Sustainable \\
\hline
\end{tabular}

Source: Computed from Statistical Abstracts of Punjab

Table V shows that all crops were sustainably cultivated from 1966-2011 except rice. The factors like injudicious use of groundwater, excess utilization of NPK fertilizers and pesticides have led to decline in crop yield, soil health and the toxic chemicals have infected groundwater and entered our food chain. Rice crop shows unsustainability in its production in the state, so there is a need of crop diversification with shift towards other crops like pulses and oilseeds. The crop diversification will not only reduce stress on its natural resources but also will sustain them for their future use, as sustainability of agricultural system is necessary for ensuring food security of a nation.

\section{CONCLUSION}

Despite assured procurement through minimum support price of rice and wheat, both area and yields

are plateauing resulting in diminishing returns for the farmers of the state. Crop yield per kg NPK have come down from 50 $\mathrm{kg}$ in initial years of the Green Revolution to $10 \mathrm{~kg}$ today [14]. As a result there is drastic reduction in crop yields of the state over the years. The over intensification of agriculture in the state has not only led to degradation of its fragile agro ecosystem but is also affecting socio-economic condition of the farmers due to high cost of production and diminishing economic returns [15]. Other ecological problems being faced are micro-nutrient deficiency, soil salinity, waterlogging, decline in water table, higher incidence of pests/diseases and pollution due to burning of crop residues of paddy and wheat crops [16]. So, there is need to shift from intensive agriculture to sustainable agriculture so as to overcome the problem of natural resource degradation in the state. This move towards sustainable agriculture is a long-term process which is only possible through proper coordination between government and farmers.

\section{REFERENCES}

[1] M. A. Altieri. (2011). Modern agriculture: Ecological impacts and the possibilities for truly sustainable farming. [Online]. Available: http://agroeco.org/fatalharvest/web_pages/article_pages/indust_ag_pa ge1.html

[2] N. S. Tiwana, N. Jerath, S. S. Ladhar, G. Singh, R. Paul, D. K. Dua, and H. K. Parwana, State of Environment; Punjab, Punjab State Council for Science \& Technology, 2007, p. 22. 
[3] J. K. Bourne, The End of Plenty: The Race to Feed a Crowded World, 1 st ed. New York, London: W. W. Norton \& Company, 2015, ch. 4, p. 58.

[4] National Project on Organic Farming, Ministry of Agriculture, India, New Delhi, 13, August, 2015, pp.19.

[5] S. Gupta, Ground Water Management in Alluvial Areas, Central Ground Water Board, 2011, p. 1.

[6] N. S. Tiwana, N. Jerath, S. S. Ladhar, G. Singh, R. Paul, D. K. Dua, and H. K. Parwana, State of Environment; Punjab, Punjab State Council for Science \& Technology, 2007, p. 23.

[7] A. S. Oyekale, "Statistical evaluation of sustainability of selected crop production in Nigeria," Life Science Journal, vol. 9, no. 4, pp. 570-578, July 1993.

[8] Withering Punjab Agriculture Can It Regain Its Leadership? International Food Policy Research Institute (IFPRI), March 2007, pp. 5.

[9] D. Russell. A Systems Approach to Sustainable Integrated Pest Management in Irrigated cotton in India, DFID Final Technical Report for R6760, Chatham, U.K: Natural Resources Institute, 1999, p. 2

[10] J. K. Bourne, The End of Plenty: The Race to Feed a Crowded World, 1st ed. New York, London: W. W. Norton \& Company, ch. 4, p. 59.

[11] R. Chand and T. Haque, "Rice-wheat crop system in indo-gangetic region - Issues concerning sustainability," Economic and Political weekly, vol. 33, no. 26, pp. 108-112, 1998.

[12] J. Singh and R. S. Sandhu, "Factors in declining crop diversification," Economic and Political Weekly, vol. 39, no. 52, 2004.
[13] National Project on Organic Farming, Ministry of Agriculture, India, New Delhi, August 2015, p. 95.

[14] P. Kumar, P. K. Joshi, C. Johansen, and M. Asokan, "Total factor productivity of rice-wheat cropping systems in India - The role of legumes," International Crops Research Institute for the Semi-Arid Tropics, Patancheru, Andhra Pradesh, India, 2000, pp. 166-175.

[15] N. S. Tiwana, N. Jerath, S. S. Ladhar, G. Singh, R. Paul, D. K. Dua, and H. K. Parwana, State of Environment: Punjab, Punjab State Council for Science \& Technology, 2007, p. 25.

[16] Module 1: Trends and Pattern of Food Production in Punjab: Bio-physical Aspect. [Online]. Available: http://gistadvisory.com/index.php?a=newspub\&b=publications

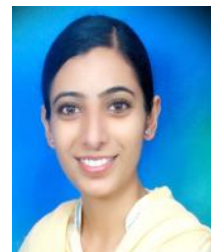

Varinderpal kaur was born in Punjab, India on January 5 . She received her M.A. degree in geography from Panjab University, Chandigarh in 2006. In 2006, she cleared National Eligibility test for Lecturership (NET) in India and joined as lecturer for a year in 2009 in the Department of Geography, Guru Nanak College, Muktsar, Punjab, India. Presently, she is pursuing her $\mathrm{Ph} . \mathrm{D}$ degree as a regular research scholar from Panjab University, Chandigarh. Her area of specialization is agricultural geography. 